NOTE

\title{
Effect of potassium permanganate stress on immune resistance and susceptibility to Lactococcus garvieae in the giant freshwater prawn Macrobrachium rosenbergii
}

\author{
Winton Cheng ${ }^{1}$, Ching-Hsien Wang ${ }^{2}$, Jiann-Chu Chen ${ }^{3, *}$ \\ ${ }^{1}$ Department of Aquaculture, and ${ }^{2}$ Institute of Tropic Agriculture, National Pingtung University of Science and Technology, \\ Pingtung, Taiwan 912, ROC \\ ${ }^{3}$ Department of Aquaculture, National Taiwan Ocean University, Keelung, Taiwan 202, ROC
}

\begin{abstract}
This work is part of a continuing series of investigations on the effect of commonly used aquaculture chemicals on the immune resistance and susceptibility of the giant freshwater prawn Macrobrachium rosenbergii to Lactococcus garvieae. The methodology has been described in earlier publications of the series. Potassium permanganate at $1.0 \mathrm{mg} \mathrm{l}^{-1}$ in tryptic soy broth (TSB) had no effect on the growth rate of $L$. garvieae. The mortality of $M$. rosenbergii challenged with $4 \times 10^{6}$ colony-forming units (cfu) prawn $^{-1}$ of TSB-grown L. garvieae was significantly greater than that of challenged controls. Addition of potassium permanganate at $1.0 \mathrm{mg} \mathrm{l}^{-1}$ in TSB significantly increased the virulence of $L$. garvieae to $M$. rosenbergii. Exposure of $M$. rosenbergii to potassium permanganate prior to challenge with TSB-grown $L$. garvieae at $4 \times 10^{6}$ and $3 \times 10^{6} \mathrm{cfu} \mathrm{prawn}^{-1}$ revealed that $96 \mathrm{~h}$ mortality was significantly lower for prawns held in water containing $0.3 \mathrm{mg} \mathrm{l}^{-1}$ of the chemical than for prawns in water containing $1.0 \mathrm{mg} \mathrm{l}^{-1}$ or no chemical. Potassium permanganate caused no significant changes in total hemocyte counts and differential hemocyte counts, compared to the control treatments. However, a concentration of $1.0 \mathrm{mg} \mathrm{l}^{-1}$ or more for $96 \mathrm{~h}$ resulted in decreased phenoloxidase activity, phagocytic activity and clearance efficiency. Respiratory burst increased with exposure to $0.3 \mathrm{mg} \mathrm{l}^{-1}$. In conclusion, treatment with potassium permanganate at $0.3 \mathrm{mg} \mathrm{l}^{-1}$ was effective in reducing $M$. rosenbergii mortality from $L$. garvieae infection, but higher concentrations had a negative effect, probably due to reduced prawn defenses.
\end{abstract}

KEY WORDS: Macrobrachium rosenbergii - Lactococcus garvieae - Potassium permanganate · Hemocyte count $\cdot$ Phenoloxidase activity $\cdot$ Respiratory burst $\cdot$ Phagocytosis

Resale or republication not permitted without written consent of the publisher

\section{INTRODUCTION}

This work is part of a continuing series of investigations examining the effects of commonly used aquaculture chemicals on the immune resistance and susceptibility of the giant freshwater prawn Macrobrachium rosenbergii to Lactococcus garvieae (Cheng \& Wang 2001, Cheng et al. 2002a,b, 2003).

Potassium permanganate is an oxidant of organic and inorganic substances in pond water that is very effective in disinfection and detoxification (Lay 1971,
Baticados \& Paclibare 1992). Its application dosage in aquaculture varies from 4 to $8 \mathrm{mg} \mathrm{l}^{-1}$ (Boyd 1990), but prawn farmers may apply excessive amounts, causing concern about the chemical's potential effect on the disease resistance and immune function of cultured prawns. The $24 \mathrm{~h} \mathrm{LC} \mathrm{LC}_{50}$ (median lethal concentration) of potassium permanganate on Macrobrachium rosenbergii postlarvae is reported to be $6.0 \mathrm{mg} \mathrm{l}^{-1}$ (Liao \& Guo 1990), but little is known about its effect on prawn resistance or on bacterial virulence. 
The objectives of this study were to examine the effects of potassium permanganate on the growth and virulence of Lactococcus garvieae, the resistance of Macrobrachium rosenbergii to L. garvieae, and the effect of potassium permanganate on immune parameters of $M$. rosenbergii.

\section{MATERIALS AND METHODS}

The methods and protocols for this work were the same as those described previously (Cheng \& Wang 2001, Cheng \& Chen 2002, Cheng et al. 2002a,b, 2003). Briefly, Macrobrachium rosenbergii prawns (10 to $12 \mathrm{~g}$ ) in the intermolt stage were obtained from a commercial farm in Pingtung, Taiwan, and acclimated for 2 wk before experimentation. For bacterial challenge experiments, test and control groups comprised 10 prawns, each in triplicate. After injection, each group was maintained in a separate $60 \mathrm{l}$ glass aquarium containing 401 aerated water.

For immune parameter assays, prawns weighed 20 to $28 \mathrm{~g}$ and were in the intermolt stage. Activity assays were carried out in triplicate or quadruplicate with test groups consisting of 2 prawns each in separate 601 glass aquaria containing $40 \mathrm{l}$ aerated water. In all tests, prawns were fed twice daily with a formulated prawn diet (Shinta Feed Company, Pingtung, Taiwan). During experiments, the water temperature was maintained at $28 \pm 1^{\circ} \mathrm{C}, \mathrm{pH} 7.3$ to 7.8 and the total water hardness was $100 \mathrm{mg} \mathrm{l}^{-1}$.

Test solutions of Lactococcus garvieae were cultured as previously described (Cheng et al. 2002a,b, 2003). The stock solution of potassium permanganate (1000 $\mathrm{mg} \mathrm{l}^{-1}$ ) was made in distilled water. Potassium permanganate was used for tests on growth and virulence at 0 (control) $0.3,0.6$ and $1.0 \mathrm{mg} \mathrm{l}^{-1}$ in $250 \mathrm{ml}$ flasks containing $50 \mathrm{ml}$ tryptic soy broth (TSB, Difco) at $30^{\circ} \mathrm{C}$ for $12,24,48$ and $120 \mathrm{~h}$. Growth was measured by optical density (OD) at a wavelength of $601 \mathrm{~nm}$ using a Model U-2000 spectrophotometer (Hitachi, Tokyo, Japan).
Lactococcus garvieae was pelleted for challenge tests by centrifugation at $7155 \times g$ for $15 \mathrm{~min}$ at $4^{\circ} \mathrm{C}$ and re-suspended in saline $(0.85 \% \mathrm{NaCl})$ at $2 \times 10^{8} \mathrm{cfu}$ $\mathrm{ml}^{-1}$. This stock bacterial suspension was diluted as appropriate with saline, and injected $(20 \mu \mathrm{l})$ into the ventral sinus of prawns. Prawns injected with an equal volume of sterile saline solution served as unchallenged controls.

Bath exposure to potassium permanganate was performed as previously described for other test chemicals (Cheng et al. 2003) at 0 (control) and 0.3, 0.6 and $1.0 \mathrm{mg} \mathrm{l}^{-1}$. Test solutions were renewed daily, and experiments ran for $144 \mathrm{~h}$ as described previously (Cheng et al. 2003). Hemolymph (100 $\mu$ l) for measurement of immune parameters was sampled individually at the beginning of the test $(0 \mathrm{~h})$ and again at 48 and 96 h. Total hemocyte counts (THC), differential hemocyte counts (DHC), phenoloxidise activity, respiratory burst, phagocytic activity and clearance efficiency were measured.

A multiple comparison (Tukey) test was conducted to examine significant differences among treatments using SAS computer software (SAS Institute). Percent data (virulence and susceptibility studies) were normalized using arcsine transformation before analysis. Differences were considered significant when $\mathrm{p}<0.05$.

\section{RESULTS AND DISCUSSION}

Lactococcus garvieae grew equally well in the TSB medium with $\left(0.3\right.$ to $\left.1.0 \mathrm{mg} \mathrm{l}^{-1}\right)$ or without potassium permanganate. In challenge tests using these cultured bacteria, all control (unchallenged) prawns survived, but death began to occur in bacterial injected prawns at $24 \mathrm{~h}$. Cumulative mortality after $96 \mathrm{~h}$ was higher using bacteria incubated in TSB containing potassium permanganate at $1.0 \mathrm{mg} \mathrm{l}^{-1}$ (Table 1).

Media or environmental parameters can affect the growth of pathogens and production of bacterial toxins (Weinberg 1985, Arp 1988). Weinberg (1985) reported that media containing iron and manganese affected

Table 1. Susceptibility of Macrobrachium rosenbergii to Lactococcus garvieae incubated in TSB (tryptic soy broth) of different potassium permanganate concentrations at $28 \pm 1^{\circ} \mathrm{C}, \mathrm{pH} 7.3$ to 7.8 . Data with different letters in same column are significantly different $(\mathrm{p}<0.05)$. Values are means \pm SD. $\mathrm{n}=$ no. of prawns

\begin{tabular}{|c|c|c|c|c|c|c|c|c|}
\hline \multirow{2}{*}{$\begin{array}{l}\text { Bacterial dose } \\
\left(\text { cfu prawn }{ }^{-1}\right)\end{array}$} & \multirow{2}{*}{$\begin{array}{l}\text { Ambient } \mathrm{KMnO}_{4} \\
\left(\mathrm{mg} \mathrm{l}^{-1}\right)\end{array}$} & \multirow{2}{*}{$\mathrm{n}$} & \multicolumn{6}{|c|}{ - Cumulative mortality (\%) } \\
\hline & & & 24 & 48 & 72 & 96 & 120 & 144 \\
\hline Control & Saline & 30 & 0 & 0 & 0 & 0 & 0 & 0 \\
\hline $4 \times 10^{6}$ & 0 & 30 & $7 \pm 6^{b}$ & $17 \pm 0^{b}$ & $23 \pm 6^{b}$ & $23 \pm 6^{b}$ & $23 \pm 6^{b}$ & $23 \pm 6^{b}$ \\
\hline $4 \times 10^{6}$ & 0.3 & 30 & $10 \pm 0^{b}$ & $20 \pm 0^{b}$ & $23 \pm 12^{\mathrm{b}}$ & $27 \pm 12^{\mathrm{ab}}$ & $27 \pm 12^{\mathrm{ab}}$ & $27 \pm 12^{\mathrm{ab}}$ \\
\hline $4 \times 10^{6}$ & 0.6 & 30 & $7 \pm 6^{b}$ & $27 \pm 6^{\mathrm{ab}}$ & $30 \pm 10^{\mathrm{ab}}$ & $30 \pm 10^{\mathrm{ab}}$ & $30 \pm 10^{\mathrm{ab}}$ & $30 \pm 10^{\mathrm{ab}}$ \\
\hline $4 \times 10^{6}$ & 1.0 & 30 & $23 \pm 6^{\mathrm{a}}$ & $37 \pm 6^{a}$ & $43 \pm 6^{a}$ & $43 \pm 6^{a}$ & $47 \pm 12^{\mathrm{a}}$ & $47 \pm 12^{\mathrm{a}}$ \\
\hline
\end{tabular}


the growth of pathogens, and modulated the yields of bacterial enzymes and toxins. Siegel (1981) reported that in complex media, the optimal iron concentration for maximal production of the neurotoxins of Clostridium botulinum was $5.4 \mu \mathrm{M}$. Previously, we have shown that ammonia, nitrite and copper sulfate also affected the growth and virulence of Lactococcus garvieae (Cheng \& Wang 2001, Cheng \& Chen 2002, Cheng et al. 2002a). These earlier results showed that copper sulfate at $0.4 \mathrm{mg} \mathrm{l}^{-1}$ and potassium permanganate at $1.0 \mathrm{mg} \mathrm{l}^{-1}$ increased the virulence of $L$. garvieae to M. rosenbergii, while ammonia- $\mathrm{N}$ at $0.26 \mathrm{mg} \mathrm{l}^{-1}$ and nitrite- $\mathrm{N}$ at $1.5 \mathrm{mg} \mathrm{l}^{-1}$ decreased the virulence.

With respect to Macrobrachium rosenbergii bathed in potassium permanganate, all unchallenged control prawns survived. However, challenges with Lactococcus garvieae at $4 \times 10^{6} \mathrm{cfu}$ prawn $^{-1}$ after prawn exposure to $0.3 \mathrm{mg} \mathrm{l}^{-1}$ potassium permanganate resulted in a significantly later $(24 \mathrm{~h})$ onset of mortality $(\mathrm{p}<0.05)$ than for prawns exposed to $0,0.6$ or $1.0 \mathrm{mg} \mathrm{l}^{-1}$ $(16 \mathrm{~h})$. After 72 to $144 \mathrm{~h}$, cumulative mortality (Table 2) of prawns exposed to $0.3 \mathrm{mg} \mathrm{l}^{-1}$ was significantly $(\mathrm{p}<0.05)$ lower $(27 \%)$ than in the unexposed control $(40 \%$ ) or other treatment (50 to $63 \%$ ) groups. Reducing the challenge dose to $3 \times 10^{6} \mathrm{cfu}_{\text {prawn }}{ }^{-1}$ (data not shown) removed significant differences in cumulative mortality at $144 \mathrm{~h}$, except for the comparison between the $0.3 \mathrm{mg} \mathrm{l}^{-1}$ group (27\%) and the $1.0 \mathrm{mg} \mathrm{l}^{-1}$ group $(43 \%)$. Survival for the other 2 groups was $33 \%$.

Previously, we have shown that the susceptibility of Macrobrachium rosenbergii to Lactococcus garvieae increases at high $\mathrm{pH}$, high temperature (Cheng \& Chen 1998), and in the presence of ammonia, nitrite and copper sulfate (Cheng \& Wang 2001, Cheng \& Chen 2002, Cheng et al. 2002a).

Bath exposure to potassium permanganate produced no significant differences in THC (total hemocyte counts) and DHC (differential hemocyte counts) compared to untreated control prawns. The mean $\pm \mathrm{SE}$ THC varied from $112 \pm 19 \times 10^{5}$ to $208 \pm 60 \times 10^{5}$ cells $\mathrm{ml}^{-1}$. The mean \pm SE DHC varied from $100 \pm 19 \times 10^{5}$ to $194 \pm 27 \times 10^{5}$ for hyaline cells, $5 \pm 3 \times 10^{5}$ to $8 \pm 4 \times 10^{5}$ for semi-granular cells, and $4 \pm 2 \times 10^{5}$ to $7 \pm 4 \times 10^{5}$ for granular cells. However, chemical exposure significantly $(p<0.05)$ decreased phenoloxidase activity (Fig. 1 ) by $23 \%$ at $48 \mathrm{~h}$ to $43 \%$ at $96 \mathrm{~h}$. In contrast, respiratory burst increased with increasing exposure time at all potassium permanganate concentrations (Fig. 2) to a maximum of $29 \%$ at $96 \mathrm{~h}$ in the $1.0 \mathrm{mg} \mathrm{l}^{-1}$ exposure group.

We previously examined the potential effect of extrinsic factors on circulating hemocyte numbers and on the immune parameters of decapod crustaceans (Cheng \& Chen 2000, 2002, Cheng \& Wang 2001, Cheng et al. 2002a,b). Similar to our earlier results with ammonia, nitrite and copper sulfate (Cheng \& Wang 2001, Cheng \& Chen 2002, Cheng et al. 2002a), we found no differences with potassium permanganate, in the present study. Also similar to our previous work with copper sulfate (Cheng \& Wang 2001) and ammonia (Cheng \& Chen 2002), in the present study phenoloxidase activity decreased after $96 \mathrm{~h}$ exposure to potassium permanganate $\left(0.3\right.$ to $\left.1.0 \mathrm{mg} \mathrm{l}^{-1}\right)$. Thus, in all

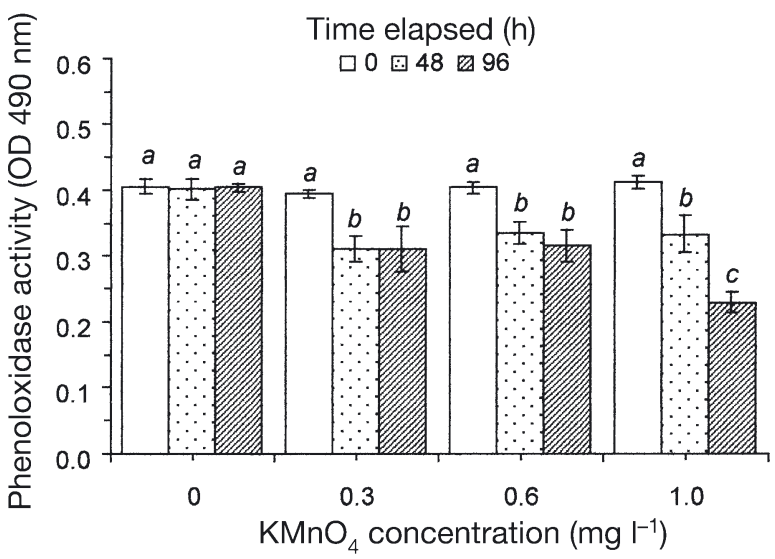

Fig. 1. Macrobrachium rosenbergii. Mean $( \pm \mathrm{SE})$ phenoloxidase activity after 0,48 and $96 \mathrm{~h}$ exposure to different concentrations of potassium permanganate. Each bar represents mean of 6 measurements. Bars with different letters for same potassium permanganate concentration are significantly different $(p<0.05)$

Table 2. Susceptibility of Macrobrachium rosenbergii to Lactococcus garvieae at different concentrations of potassium permanganate. Data with different letters in same column are significantly different $(p<0.05)$ among treatments. Values are means \pm SD. $\mathrm{n}=$ no. of prawns

\begin{tabular}{|c|c|c|c|c|c|c|c|c|c|}
\hline \multirow{2}{*}{$\begin{array}{l}\text { Bacterial dose } \\
\left(\text { cfu prawn }^{-1} \text { ) }\right.\end{array}$} & \multirow{2}{*}{$\begin{array}{c}\text { Ambient } \\
\mathrm{KMnO}_{4}\left(\mathrm{mg} \mathrm{l}^{-1}\right)\end{array}$} & \multirow[t]{2}{*}{$\mathrm{n}$} & \multicolumn{7}{|c|}{ - Cumulative mortality (\%) } \\
\hline & & & 16 & 24 & 48 & 72 & 96 & 120 & 144 \\
\hline Control & 1.0 & 30 & 0 & 0 & 0 & 0 & 0 & 0 & 0 \\
\hline $4 \times 10^{6}$ & 0 & 30 & $10 \pm 10^{\mathrm{ab}}$ & $23 \pm 6^{\mathrm{ab}}$ & $33 \pm 12^{\mathrm{ab}}$ & $40 \pm 0^{\mathrm{b}}$ & $40 \pm 0^{\mathrm{b}}$ & $40 \pm 0^{b}$ & $40 \pm 0^{\mathrm{b}}$ \\
\hline $4 \times 10^{6}$ & 0.3 & 30 & $0 \pm 0^{\mathrm{b}}$ & $13 \pm 6^{\mathrm{b}}$ & $23 \pm 6^{b}$ & $27 \pm 6^{\mathrm{c}}$ & $27 \pm 6^{c}$ & $27 \pm 6^{c}$ & $27 \pm 6^{\mathrm{c}}$ \\
\hline $4 \times 10^{6}$ & 0.6 & 30 & $3 \pm 6^{\mathrm{ab}}$ & $27 \pm 6^{\mathrm{ab}}$ & $50 \pm 10^{a}$ & $53 \pm 6^{\mathrm{a}}$ & $57 \pm 6^{\mathrm{a}}$ & $57 \pm 6^{\mathrm{a}}$ & $57 \pm 6^{\mathrm{a}}$ \\
\hline $4 \times 10^{6}$ & 1.0 & 30 & $13 \pm 6^{\mathrm{a}}$ & $33 \pm 6^{\mathrm{a}}$ & $50 \pm 0^{\mathrm{a}}$ & $50 \pm 0^{\mathrm{a}}$ & $57 \pm 6^{\mathrm{a}}$ & $60 \pm 10^{\mathrm{a}}$ & $63 \pm 12^{a}$ \\
\hline
\end{tabular}




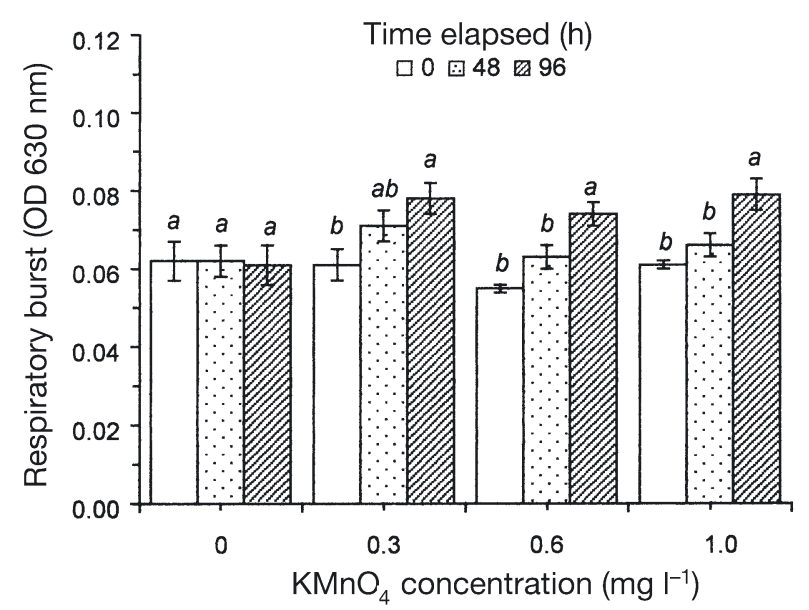

Fig. 2. Macrobrachium rosenbergii. Mean $( \pm \mathrm{SE})$ respiratory burst after 0, 48 and $96 \mathrm{~h}$ exposure to different concentrations of potassium permanganate. Further details as in Fig. 1

our similar studies, the recorded decrease in phenoloxidase activity was not a consequence of reduced THC or altered DHC.

The increased release of superoxide anion upon exposure to potassium permanganate in the present study was also similar to our earlier results with ammonia, nitrite and copper sulfate (Cheng \& Wang 2001, Cheng \& Chen 2002, Cheng et al. 2002a), whereby moderate concentrations increased immunity and high concentrations caused cytotoxicity (Muñoz et al. 2000). Further research on activities of superoxide dismutase, catalase and peroxidase (Holmblad \& Söderhäll 1999) are necessary to explain the production of ROIs (reactive oxygen intermediates) under potassium permanganate stress.

There was a small (4 to $6 \%$ ) but significant decrease in phagocytic activity during exposure to $0.6-1.0 \mathrm{mg}$ $\mathrm{l}^{-1}$ potassium permanganate at $96 \mathrm{~h}$ compared to unexposed controls (Fig. 3). In contrast, larger decreases in Lactococcus garvieae clearance efficiency were observed (Fig. 4) by $48 \mathrm{~h}$ at $0.6 \mathrm{mg} \mathrm{l}^{-1}(47 \%)$ and $1.0 \mathrm{mg} \mathrm{l}^{-1}(147 \%)$. The largest decrease of $155 \%$ occurred at $96 \mathrm{~h}$ in $1.0 \mathrm{mg} \mathrm{l}^{-1}$. In an earlier study, we also showed that both phagocytic activity and clearance efficiency to $L$. garvieae decreases after exposure to nitrite-N (Cheng et al. 2002a).

In conclusion, our results suggest that $0.3 \mathrm{mg} \mathrm{l}^{-1}$ potassium permanganate in aquaculture ponds effectively reduces mortality of Macrobrachium rosenbergii due to Lactococcus garvieae infection, whereas higher levels are detrimental. The reason for the reduced mortality is unknown, but it was not due to any inhibitory effect on $L$. garvieae growth or to any improvement in the prawn immune parameters we measured.

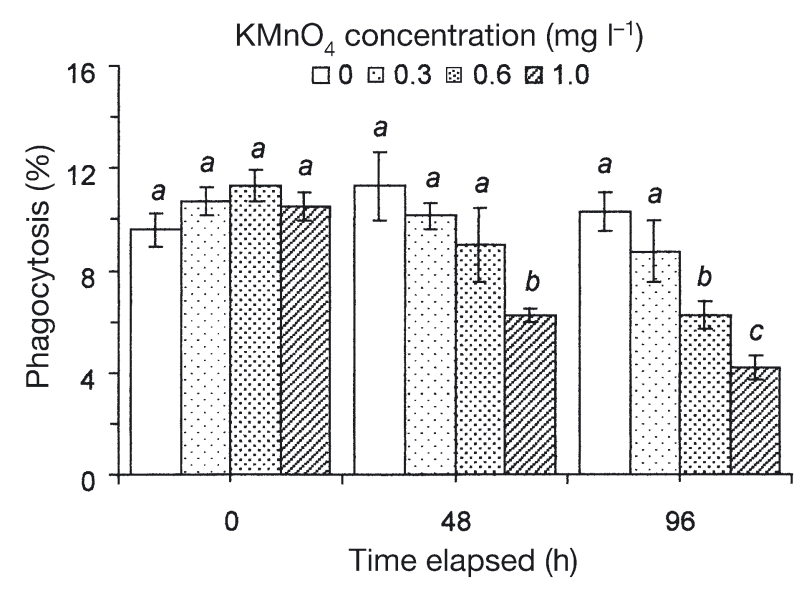

Fig. 3. Macrobrachium rosenbergii. Mean $( \pm \mathrm{SE})$ phagocytic activity after 0,48 and $96 \mathrm{~h}$ exposure to different concentrations of potassium permanganate. Each bar represents mean of 8 measurements. Bars with different letters for same exposure time are significantly different $(p<0.05)$

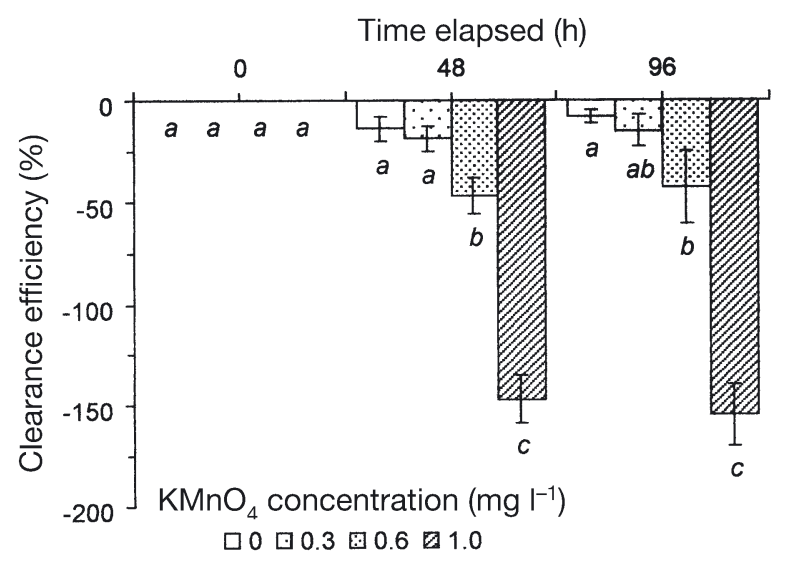

Fig. 4. Macrobrachium rosenbergii. Mean $( \pm$ SE) clearance efficiency during exposure to different concentrations of potassium permanganate. Further details as in Fig. 3

Acknowledgements. This work was supported by a grant from the Council of Agriculture of the Republic of China (COA 89-1.2-04-29). We thank Dr. S. C. Sheu, Associate Professor of Department of Food Science for the use of the ELISA reader, Mr. C. H. Chang and Mr. C. H. Liu for their assistance during the experiment, and Mr. Y. H. Chen, University of California, Berkeley, for his critical review of the manuscript.

\section{LITERATURE CITED}

Arp LH (1988) Bacterial infection of mucosal surfaces: an overview of cellular and molecular mechanisms. In: Roch JA (ed) Virulence mechanisms of bacterial pathogens. American Society for Microbiology, Washington, DC, p 3-27 
Baticados MCL, Paclibare JO (1992) The use of chemotherapeutic agents in aquaculture in the Philippines. Diseases in Asian Aquaculture. 1. Proceedings of the First Symposium on Diseases in Asian Aquaculture, 26-29 November 1990, Bali, Indonesia. Fish Health Section, Asian Fisheries Society, Manila, Philippines, p 531-546

Boyd CE (1990) Water quality in ponds for aquaculture. Shrimp Mart, Songkhla, Thailand

Cheng W, Chen JC (1998) Enterococcus-like infections in Macrobrachium rosenbergii are exacerbated by high $\mathrm{pH}$ and temperature but reduced by low salinity. Dis Aquat Org 34:103-108

Cheng W, Chen JC (2000) Effects of pH, temperature and salinity on immune parameters of the freshwater prawn Macrobrachium rosenbergii. Fish Shellfish Immunol 10:387-391

Cheng W, Chen JC (2002) The virulence of Enterococcus to freshwater prawn Macrobrachium rosenbergii and its immune resistance under ammonia stress. Fish Shellfish Immunol 12:97-109

Cheng W, Wang CH (2001) The susceptibility of the giant freshwater prawn Macrobrachium rosenbergii to Lactococcus garvieae and its resistance under copper sulfate stress. Dis Aquat Org 47:137-144

Cheng W, Liu CH, Chen JC (2002a) Effect of nitrite on interaction between the giant freshwater prawn Macrobrachium rosenbergii and its pathogen Lactococcus garvieae. Dis Aquat Org 50:189-197

Editorial responsibility: Timothy Flegel,

Bangkok, Thailand
Cheng W, Liu CH, Hsu JP, Chen JC (2002b) Effect of hypoxia on the immune response of giant freshwater prawn Macrobrachium rosenbergii and its susceptibility to pathogen Enterococcus. Fish Shellfish Immunol 13:351-365

Cheng W, Wang CH, Chen JC (2003) Effect of benzalkonium chloride stress on immune resistance and susceptibility to Lactococcus garvieae in the giant freshwater prawn Macrobrachium rosenbergii. Dis Aquat Org 53:223-229

Holmblad T, Söderhäll K (1999) Cell adhesion molecules and antioxidative enzymes in a crustacean, possible role in immunity. Aquaculture 172:111-123

Lay BA (1971) Applications for potassium permanganate in fish culture. Trans Am Fish Soc 100:813-815

Liao IC, Guo JJ (1990) Studies on the tolerance of postlarvae of Penaeus monodon, P. japonicus, $P$. semisulcatus, $P$. penicillatus, Metapenaeus ensis and Macrobrachium rosenbergii to copper sulfate, potassium permanganate and malachite green. COA Fish Ser (Counc Agric) 24:90-94

Muñoz $M$, Cedeño $R$, Roríguez $J$, van der Knaap WPW, Mialhe E, Bachère E (2000) Measurement of reactive oxygen intermediate production in haemocytes of the penaeid shrimp, Penaeus vannamei. Aquaculture 191:89-107

Siegel LS (1981) Effect of iron on growth and toxin production by Clostridium botulinum type A. Curr Microbiol 6:127

Weinberg ED (1985) Enzymes, nutrition, and virulence. In: Holder IA (ed) Bacterial enzymes and virulence. CRC Press, Boca Raton, FL, p 1-16

Submitted: September 23, 2002; Accepted: July 9, 2003 Proofs received from author(s): September 22, 2003 